-and a large portion of the bibliography as well-every librarian has an obligation to read in order to gain an understanding of the processes which communicate so many ideas, impressions and attitudes to so many people literally every hour of every day of every year. The results of these communication processes, as they are embodied in one physical form or another, constitute the materials of which our libraries are made.

Librarians who read the volume will be quick to notice one or two obvious omissions. It has nothing to say about audience research in the motion picture field, in the periodical field and in the book field. It is possible, of course, to dismiss the motion picture as having dedicated itself to enter- tainment, pure and simple; but research has shown that attitudes and information are most effectively transmitted by the motion picture-even when the intent is only entertainment. The omission of magazines is less defensible, for they rival newspapers in number, in quality of content and in probable effect. The librarian will most regret the omission of specific attention to research in the book field. Perhaps this omission will serve to point out the need, and will cause librarians and publishers to undertake the necessary research to provide some of the same kinds of answers that the radio and the press is using so effectively.-LeRoy Charles Merritt, School of Librarianship, University of California.

\title{
Public Relations
}

Public Relations for Colleges and Universities; a Manual of Practical Procedure. By Christopher Edgar Parsons. Stanford University, Stanford University Press, 1946, 6rip.

In the short space of $6 \mathrm{I}$ pages, Christopher Edgar Parsons has written a different kind of book on public relations, and an important one. In his own words the author attempts, successfully for the most part, "To define and explain the administrator's own position and function as to public relations, and, further, to construct a sound public relations procedure."

The author is a forceful writer and gives the impression that he writes from a deep knowledge of the subject. He sticks closely to the fundamentals of public relations as opposed to publicity. After pointing out the importance of public relations to an educational institution, he emphasizes that the only firm foundation upon which public relations can be successfully developed is prestige. Prestige, he says, does not depend on wealth or size but results from "public recognition of a worthy undertaking well done." Among the several pitfalls into which institutions are prone to fall and which militate against prestige, one is of particular interest to this reviewer; that of accepting gifts (white elephants) which lead to over-expansion and necessitates the spreading of already meager resources thinner and thinner. $\mathrm{Li}$ - brarians have frequently been placed in this situation.

All people connected with the institution in any way, and some who are not, comprise the real instruments of good public relations. The people connected with a college or university are rated in descending order of importance as follows: faculty, student body, alumni, parents of students, and trustees. These groups and all their members are possible agents to help in the creation of prestige. The problem lies in organizing and directing their efforts.

First of all the way in which the institution is to excel must be determined. Then a committee of to leaders should be selected from these groups to work with the administrator in planning and developing the program. The author shows a profound knowledge of the principles of leadership in the paragraphs dealing with the selection of these men. If these selections are wisely made the president will have a nucleus of informed, intelligent and capable support which constitute a strong base from which to launch an effective continuing program of public relations.

The problem at this point is to put the people to work and to make them feel a part of the program. The solution lies in acquainting each group, through the leaders, with the definition of the institution's area of prestige and by inviting suggestions from 
each group as to how it can be most helpful. Many members of each group will have ideas, and perhaps "a pebble in his shoe" which he would like to cast out. After getting rid of these pebbles by explanation or adjustment, the first real step in satisfactory public relations will have been realized and the way for group cooperative efforts will be cleared. The more enduring efforts may then be emphasized and the groups will be ready to put them into effect. The reviewer is sorely tempted to develop the author's treatment of the ways in which each group may make its contributions but the limits of space must be observed. These paragraphs are provocative in thought and ideas.

For the permanent operation of the program, the participants must be made to feel that their work is effective and that their efforts are recognized and appreciated. This requires coherent planning, logical organization, continual assistance and guidance under a director of the consolidated program who works "as close to the administrator as his own skin."

The establishment of such a program may require from three to five years. The first year may be devoted to defining the institution's area of prestige through the administrator's personal thinking and through ideas gleaned from advisers among the faculty, trustees, students, alumni, and others. A nucleus of workers will develop during the first year, and during the second the nucleus will grow in size and begin to function. During the third year the programs will have developed and efforts to put them into operation will begin. In the fourth and fifth years the nuclei will expand greatly and will be steadily at work in well thought out programs which, if continued, will bring in steady dividends to the institution.

Whether or not all the points considered in the book are valid is of small consequence. Some few are doubtful. The book as a whole, however, is an important contribution to the field of public relations in educational institutions. It should be valuable to both the president and to the director of public relations. It should be on the director's shelves along with the more detailed books on the same subject by Benjamin Fine, Emerson Reck, and Stewart Harrall. These volumes are more or less manuals of publicity techniques whereas the volume under review is a comprehensive yet concise examination of the methods through which an educational institution can utilize its various component parts in developing and carrying on a well rounded, effective public relations program. These other titles implement rather than duplicate the contents of $\mathrm{Mr}$. Parsons' volume. All of them should be known to the college or university librarian, who as a responsible officer is an important link in the public relations program of the institution he represents.-W. Porter Kellam, University of North Carolina Library.

\section{American Universities, Colleges, and Junior Colleges}

American Universities and Colleges. $5^{\text {th }}$ ed. Edited by A. J. Brumbaugh. Washington, D.C., American Council on Education, 1948. 1054p.

American Junior Colleges. 2d ed. Edited by Jesse P. Bogue. Washington, D.C. American Council on Education, 1948. 537p.

Most librarians in academic institutions know of the usefulness of American Universities and Colleges. The first edition of this work, issued in 1928, contained data of 399 accredited institutions; the present fifth edition, of 820 institutions. The new edition has not only grown in the number of universities and colleges included; it has also grown in the amount of material included about the institutions. For example, specific information relating to veterans and foreign students has been added.

Information about the library in each institution is usually limited to size (in volumes), number of government documents held, number of periodicals received regularly, volumes added and funds spent for acquisitions during 1946-47, and special collections owned. Some of themajor institutions, such as Chicago, Columbia, and Yale have listed collections in considerable detail. No information, however, is available about the notable collections at Harvard.

Special note should be taken of the sections 